\title{
Disulfide-Rich Peptides in Drug Development
}

\section{İlaç Geliştirmede Disülfit-Zengin Peptidler}

\section{Şeyda Kara ${ }^{\circledR}$ and Muharrem Akcan ${ }^{*}$}

Department of Biochemistry, Faculty of Arts and Sciences, Kütahya Dumlupınar University, Kütahya, Turkey.

\section{ABSTRACT}

eptides are important biomolecules in drug development with their high specificities to their targets. Many peptidebased drug candidates have been increasingly involved in clinical and preclinical studies. Unfortunately, peptides have some disadvantages such as poor metabolic stability, poor oral bioavailability and high production costs. These problems can be overcome by modifications that have been inspired from highly stable disulfide-rich peptides already found in nature. This review describes the structure and bioactivity of disulfide-rich peptides and their development with various modifications to become candidate molecules in drug design and development studies.

\section{Key Words}

Therapeutic peptides, drug development, cyclotides, peptide stability.

eptidler, ilaç geliştirmede hedeflerine yüksek özgüllükleri olan önemli biyomoleküllerdir. Birçok peptid-bazlı ilaç adayı, klinik ve preklinik çalışmalarda giderek daha fazla yer almaktadır. Ne yazık ki, peptidlerin zayıf metabolik stabilite, zayıf oral biyoyararlanım ve yüksek üretim maliyetleri gibi bazı dezavantajları vardır. Bu problemler, hali hazırda doğada bulunan oldukça stabil disülfit bakımından zengin peptidlerden ilham alınarak yapılan modifikasyonlar ile çözülebilir. Bu derlemede disülfit-zengin peptidlerin yapı ve biyoaktiviteleri ve ilaç tasarım ve geliştirme çalışmalarında aday moleküller haline gelmek için çeşitli modifikasyonlarla geliştirilmeleri anlatılmaktadır.

\section{Anahtar Kelimeler}

Terapötik peptidler, ilaç geliştirme, siklotitler, peptid stabilitesi.

Article History: Received: Jan 20, 2020; Revised: Mar 12 2020; Accepted: Mar 15, 2020; Available Online: Apr 1, 2020. DOI: https://doi.org/10.15671/hjbc.658764

Correspondence to: M. Akcan, Department of Biochemistry, Faculty of Arts and Sciences, Kütahya Dumlupınar University, Kütahya, Turkey.

E-Mail: muharrem.akcan@dpu.edu.tr 


\section{THERAPEUTIC PEPTIDES}

Therapeutic molecules are divided into two main clasight and protein-structured biologicals with molecular weight greater than $5000 \mathrm{Da}$. Although small molecule therapeutics are known to be stable molecules as they do not degrade when taken into the body, they have low specificity to their targets and hence side effects, as they can create undesirable interactions with other regions outside the active site of the target molecule. On the other hand, because of their large molecular structures, biologicals bind to their targets with high specificity and thus produce less side effects. Therefore, the number of biologicals approved by drug authorities has increased in recent years [1-3]. However, biologicals are easily degraded by proteases because of their protein-based structures, resulting in reduced bioavailability and hence a more limited effect. In today's pharmaceutical research and development, many studies have been carried out to eliminate these disadvantages of small molecule therapeutics and biologicals. In recent years, peptides have become molecules of interest in such studies. Peptides ranging in molecular weight from
500 Da to 5000 Da have advantages such as high target specificity, less toxicity and less deposition in tissues as biologicals (Figure 1). They can also easily pass through the cell walls as small molecules and interact with their target molecules.

Peptides are biomolecules formed by binding of 40 and/ or fewer amino acids to each other by peptide bonds. The therapeutic efficacy of the peptides has been extensively studied and is of great interest in the diagnosis and treatment of many diseases [4].

To date, peptides have been isolated from many organisms, particularly from microorganisms, animals and plants, and their therapeutic efficacy has been studied by many research groups [5-8]. These peptides are used in today's drug screening, design and development studies, and some have already been approved as drugs. For example, cyclosporin A, isolated from Tolypocladium inflatumizole fungus, is a peptide having 11 residues and has oral bioavailability [9-11]. Although its antifungal activity is known at first, it is currently used as an immunosuppressant in organ transplants [12]. Linaclotide, another peptide drug that can be taken orally, interacts

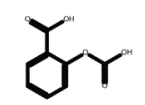

Small Molecules $<500 \mathrm{Da}$

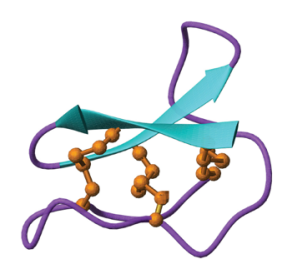

Peptides 500-5000 Da

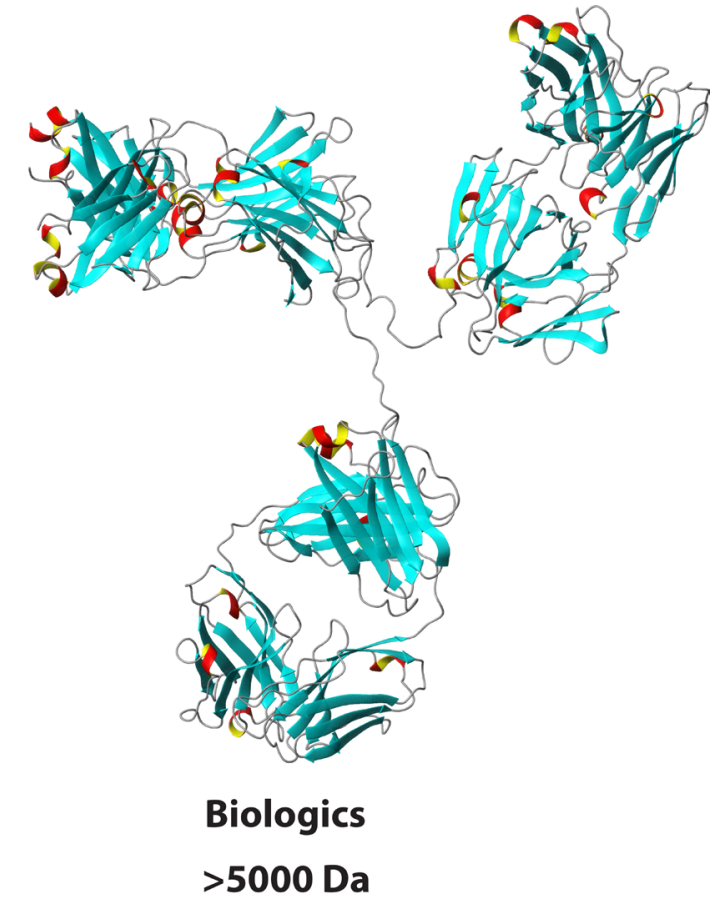

Figure 1. Illustration of therapeutic molecule structures by molecular weight. Peptides are therapeutic biomolecules between small molecules and biologicals based on their molecular weight and are used in today's pharmaceutical research and development. Aspirin, kalata B1 (PDB code: 1NB1) and IgG2a (PDB code: 1IGT) monoclonal antibody are given as examples for small molecules, peptides and biologicals, respectively. Kalata B1 and IgG2a molecular structures were prepared with MOLMOL [Figure was adapted from reference 6]. 

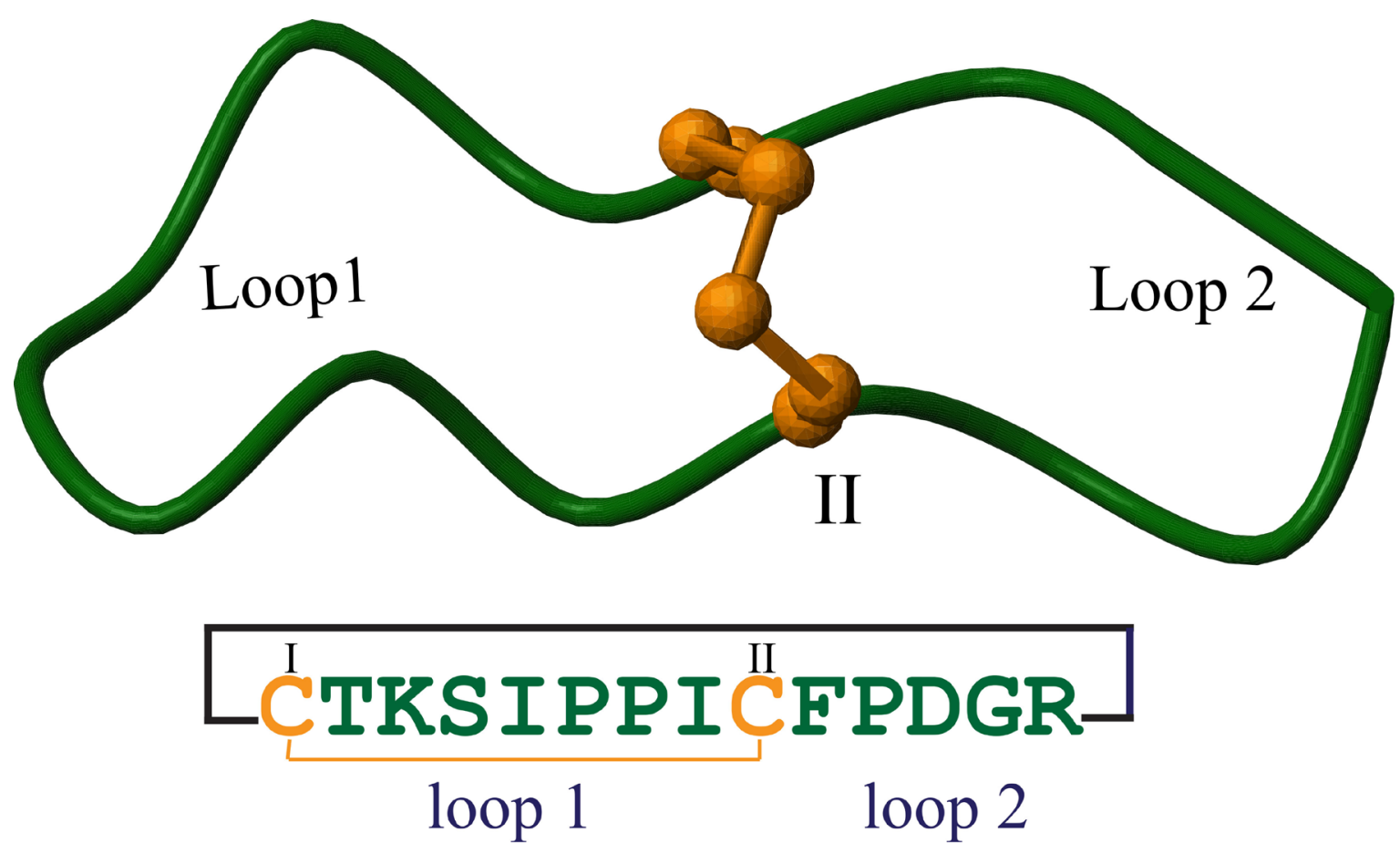

Figure 2. The three-dimensional structure and amino acid sequence of SFTI-1 peptide (PDB code: 1JBL). The peptide has 14 residues and a disulfide bridged cyclic backbone structure. The peptide backbone is shown in green, and the Cys amino acids forming the disulfide bridge are shown in orange. Molecular structure was prepared with MOLMOL [Figure was adapted from reference 6].

with guanylate cyclase $\mathrm{C}$ and is used in the treatment of irritable bowel syndrome. This peptide drug has 14 residues and three disulfide bridges. Colistin, a peptide drug isolated from Paenibacillus polymyxa, is used in infectious diseases caused by gram (-) bacteria. Another drug with antimicrobial activity is daptomycin which was approved in 2013 by the American Food and Drug Administration (FDA), is a lipopeptide isolated from Streptomyces roseosporus.

Peptides, particularly from venoms, saliva and skin secretions of animals, have an important place in the development of peptide-based drugs because of their high therapeutic potentials. Eptifibatide, isolated from snake venom has been used clinically since 1998 for its anticoagulant activity [13]. Captopril, another peptide drug isolated from snake venom, is used in the treatment of hypertension with angiotensin converting enzyme (ACE) inhibitor activity [14]. Tirofiban, Batroxobin, Hemocoagulase, Ximelagatran are other peptide drugs in the market derived from snake venoms [15-18]. Another therapeutic peptide of animal origin is Exenatide, which is isolated and developed from the saliva of the Gila monster lizard. This C-terminal amidated and 39 amino acid long peptide was approved by FDA in 2005 for the treatment of Type 2 diabetes [19].
Peptides derived from conus species of marine snails living in tropical oceans are called conotoxins $[20,21]$. Conotoxins are disulfide-rich linear biomolecules with 12-40 amino acids. Because of their high potency and selectivity on potassium, sodium, calcium and chloride ion channels and receptors, conotoxins are considered as important therapeutics $[22,23]$. The synthetic version of 25 amino acid-long MVIIA peptide derived from the venom of the $C$. magus cone snail is the first conotoxin-type peptide drug used for the treatment of chronic pain under the generic name of Ziconotide (Prialt ${ }^{\circledR}$ ) $[24,25]$. Another promising conotoxin is Vc1.1 peptide from the venom of $C$. victoria and has 16 amino acids with two disulfide bonds. It can inhibit nicotinic acetylcholine receptors (nAChR) and its synthetically cyclized version has higher stability compared to lineer version [26].

Chlorotoxin is a 36 amino acids long scorpion venom peptide isolated from Leiurus quinquestriatus venom. Three-dimensional structure of chlorotoxin has been identified by Nuclear Magnetic Resonance (NMR) spectroscopy [27]. It has an $\alpha$-helix and three $\beta$-sheets structure with four disulfide bonds. A synthetic iodine derivative of chlorotoxin, ${ }^{131}$ I-TM-601, was reported as 

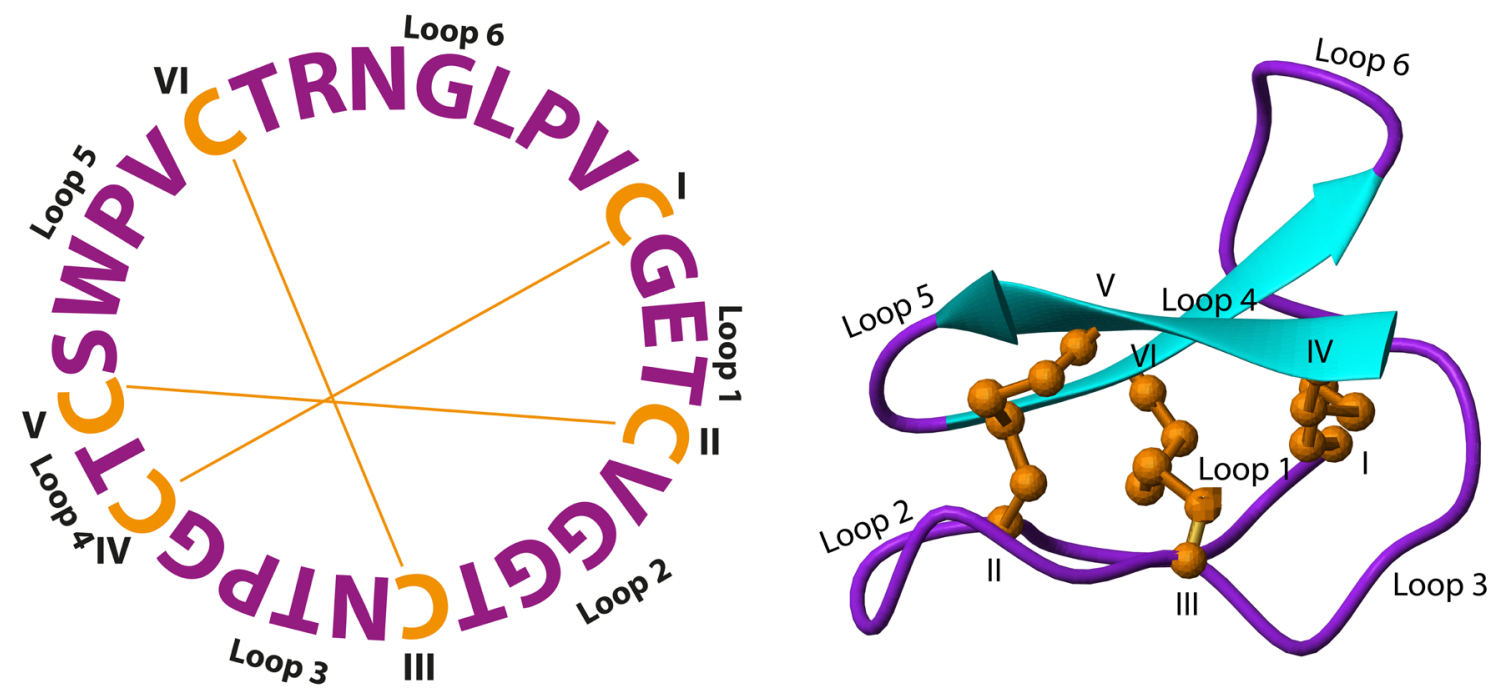

Figure 3. Amino acid sequence and three-dimensional structure of Kalata B1 peptide (PDB code: 1NB1). The peptide has a cyclic backbone structure and six Cys residues forming the three disulfide bridges. The peptide backbone is shown in purple, and the Cys amino acids and the disulfide bonds are shown in orange. The three-dimensional structure on the right was prepared with MOLMOL [Figure was adapted from reference 6].

it can bind to glioma, but not to normal tissues [28]. It has been reported that chlorotoxin can also bind Annexin 2 which is an extracellular matrix protein of cancer cells. This cancer cell selectivity of chlorotoxin has been utilized to develop a conjugated molecule of the peptide with a fluorescent dye. The conjugate is called "tumor paint" which can highlight brain tumor cells under fluorescent light during surgical resection $[29,30]$ and help surgeons to distinguish cancer cells from normal cells more precisely. Tozuleristide (BLZ-100) is a version of tumor paint developed by conjugating chlorotoxin with the near-infrared fluorophore indocyanine green for imaging pediatric brain tumors and it is now in phase I clinical trials [31].

In addition to conotoxins and chlorotoxin and other venom peptides, macaque and baboon leukocytes, frog skin secretions, spider hemocytes and bee venoms are also other rich sources of bioactive peptides that have been under investigation for the development of peptide therapeutics for many decades [32-35].

Plants are other important sources of bioactive peptides that are frequently used in drug research and development studies due to their high stability and cell penetration abilities. They have also antimicrobial, anti-HIV and anticancer bioactivities [36]. For example, trypsin inhibitor SFTI-1 peptide isolated from sunflower plant is one of the most studied plant-derived peptides with high stability. It is a 14 amino acid long single disul- fide-bridged cyclic peptide with a lysine residue which provide the trypsin inhibitor activity. In addition to the cyclic backbone and the single disulfide bridge, hydrogen bonds between the two antiparallel $\beta$-sheets also have a significant effect on the stability of SFTI-1 [37]. While having a homologous sequence to Bowman-Birk inhibitors that inhibit trypsin/chymotrypsin enzymes, it has also been reported to inhibit the matriptase enzyme that induces cancer cell metastasis $[38,39]$. In Figure 2, the three-dimensional solution structure and amino acid sequence of SFTI-1 are shown.

Because of their diverse and invaluable bioactivities, peptides have an important role in pharmaceutical research and development studies. However, the major challenges in the development of peptide-based drugs are their poor stability and consequently poor oral bioavailability. In order to overcome this problem, the drug development studies firstly discover the peptide or peptide epitope and aims to increase the stability and bioavailability of this epitope by various strategies. Strategies for increasing peptide stability has been initially inspired by the structure and bioactivity of plant derived disulfide-rich peptides (e.g. cyclotides) found in nature.

\section{Disulfide Rich Peptides; Cyclotides}

In the 1960s, Norwegian Doctor Lorents Gran observed that women living in the Democratic Republic of Congo in Africa boiled Oldenlandia affinis plant and drank its 
tea to facilitate childbirth. It has been reported that the main active ingredient in this uterotonic plant extract is the kalata-kalata peptide, which does not denature despite boiling in water and is resistant to proteolytic enzymes when administered orally [40]. Approximately 25 years later, the peptide was renamed as kalata B1 and was reported to have a cyclic peptide backbone and a cystine knot motif arranged by its three disulfide bonds (Figure 3) [41,42].

Cyclotides are found in Rubiaceae, Violaceae, Cucurbitacea, Solanaceae and Fabaceae plant families [43]. In the following years, new cyclotides were isolated from Panicum laxum, a member of the single-core Poaceae plant family $[44,45]$. They are cyclic peptides with 28 37 residues, of which six are Cys residues. The peptide sequence between the two Cys amino acids is called "loop". In loop 1, the cyclotides generally contain a total of 3-4 amino acids with a Glu residue, 4-8 amino acids in loop 2, 3-7 amino acids in loop 3, only one amino acid (Ser, Thr or lle) in loop 4, 4-5 amino acids in loop 5, and 5-8 amino acids in loop six [46-48]. The lists and activities of cyclotides are deposited in a database called cybase (http://www.cybase.org.au/) [49].
The three disulfide bonds of cyclotides are arranged in themselves to form the cyclic cystine knot (CCK) structural motif. This CCK motif, which is the most characteristic feature of cyclotides, is the ring structure formed by Cys1-Cys4 and Cys2-Cys5 disulfide bridges together and the third disulfide bridge formed by Cys3-Cys6 embed this ring to form CCK motif (Figure 4). This motif is extremely important as it gives chemical, thermal and enzymatic resistance to the peptide structure [50]. Cyclotides have an important role in drug research and development due to the outstanding stability of CCK motif and the cyclic backbone, their tolerance to sequence modifications, and the ability of some cyclotides to cross the cell membrane.

Cyclotides are divided into three sub-classes as Möbius, bracelet and trypsin inhibitors. The Möbius and bracelet cyclotides are similar but are separated by the presence or absence of a cis-Trp-Pro bond in loop 5, respectively. Examples of the most commonly used cyclotides in drug design studies as Möbius and Trypsin inhibitors are kalata B1 and MCoTI-II peptides, respectively. Bracelet subfamily peptides are not preferred very much in the studies due to the lack of conformation in the natural form of the peptide after they are synthetically produced [51,52].

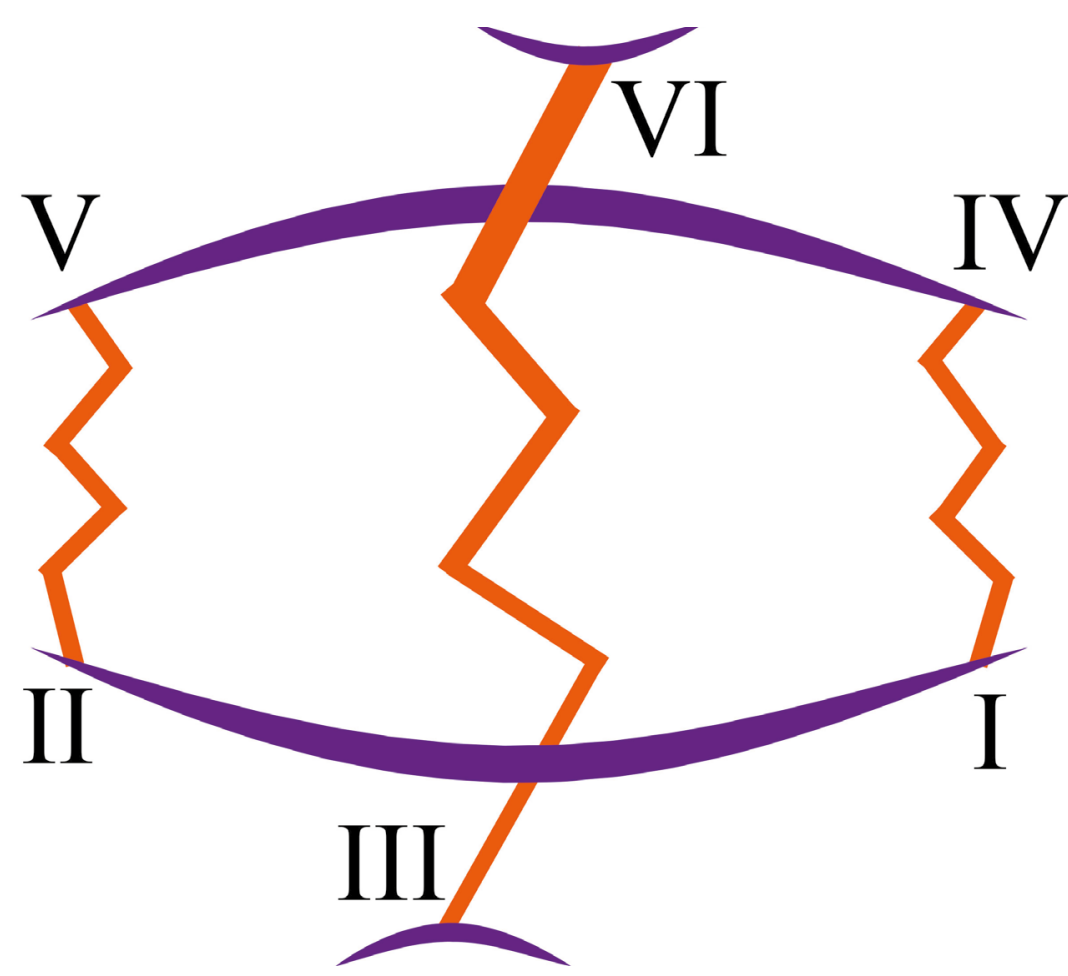

Figure 4. Cyclic cystine knot (CCK) motif. Three disulfide bonds are arranged in themselves in which two of them form a ring and the third one embeds this ring to form a knot motif. The CCK motif provides outstanding resistance to peptides against chemical, thermal and enzymatic effects. The peptide backbone is shown in purple and disulfide bridges in orange [Figure was adapted from reference Figure was adapted from reference]. 
In addition to the high stability of cyclotides, it has been shown that they also have many important bioactivities. The most important task of these peptides is to protect the plant against insects that was reported in a study in which cyclotides can inhibit the growth of Helicoverpa larvae (insecticide) [53]. Cyclotides have also been reported in many studies to have nematicide, molluscicide, anti-HIV and antimicrobial activities [54-57]. Because of these remarkable pharmacological properties, many research groups have been investigating cyclotides for a couple of decades.

The positive charge that gives the antimicrobial effect to cyclotides is extremely important for their membrane activities. The positively charged cyclotides can electrostatically interact with the negative charge on the membranes of tumor cells, bacteria and pathogens, break down the membranes of the cells and enter them. The bioactivities of Möbius and bracelet cyclotides change in relation to the presence or absence of phosphotylethanolamine (PE), one of the membrane phospholipids found in the membrane, and high affinities of these cyclotides against PE have been reported [58,59] However, MCOTI-II, which does not have an affinity for $P E$, can enter the cell as a result of its interaction with phosphatidylinositol (PI) and phosphate acids (PA) in the membrane $[60,61]$. Furthermore, the first loop of cyclotides, particularly the Glu residue, is extremely important for membrane degrading activity [62]. The cytotoxic effects of cyclotides varv $A$ and varv $F$ belonging to the Möbius subfamily and cycloviolacin $\mathrm{O} 2$ from the bracelet subfamily were also examined and these cyclotides showed selective cytotoxic effects by interacting with cancer cells containing more negatively charged phosphatidylserine (PS) in their membranes compared to normal cells [63-65].

\section{Strategies for Enhancing Peptide Stability}

Although peptides have significant bioactivities, they degrade as proteins when taken orally due to the low $\mathrm{pH}$ of stomach content and their susceptibility to proteases such as trypsin, chymotrypsin, pepsin and carboxy peptidases. If the peptide medications that should be taken frequently for treatment would be taken by injection which is not preferred by the patients. Peptide drugs are given by parenteral injection due to their poor oral bioavailability For example, the peptide hormone insulin is administered by injection to treat diabetes because of its susceptibility to various proteases in the body. Therefore, the stability of the peptide-based drug leads needs to be enhanced with various strategies to be resistant to proteases without affecting peptide bioactivity. Cyclization of peptide backbone, grafting and addition of unnatural amino acids to the peptide sequence or modifications of amino acids are important strategies for this purpose. In Figure 5 below, strategies that can be applied to increase peptide stability are given.

\section{Cyclization of Peptide Backbone}

Perhaps the most important strategy to improve the peptide stability is the cyclization of linear peptide backbone that has been inspired by the emergence of cyclic peptides with high stability (e.g. cyclotides) [66-70]. It has been possible to obtain peptide structures that are more resistant to proteolytic enzymes by using bridges formed between amino acids side chains or joining the peptide backbone $\mathrm{N}$ and C-terminals using linker residues that has an appropriate length of the distance between the terminals of the peptide without disrupting the overall three-dimensiona structures but to increase the peptide stability.

Conotoxins have limited stability to proteolytic enzymes due to their linear frameworks. The cyclization method has been one of the most preferred method for increasing the stability of these peptides. The most famous example is the cyclization of $\alpha$-conotoxin Vc1.1 peptide backbone reported in 2010 [71]. In this study, considering the three-dimensional structure, the peptide was cyclized with six linker residues (GGAAGG) in accordance with the distance between the $\mathrm{N}$ - and $\mathrm{C}$-terminals of Vc1.1. After cyclization, the three-dimensional structure of the peptide was preserved as native fold and the peptide stability was increased by $46 \%$ compared to linear Vc1.1. cVc1.1 has been also more stable in simulated gastric fluid and simulated intestinal fluid compared to linear Vc1.1 and orally active in rat model used in the study. Another example is the cyclization of an 18 amino acid long Gomesin peptide isolated from hemocytes of spider Acanthoscurria gomesiana. After cyclization, it's found that stability and cytotoxicity of this antimicrobial peptide to HeLa cells increased compared to its linear version [72]

Peptide backbone cyclization has been successfully applied on many other linear bioactive peptides, particularly on conotoxins, scorpion venom peptide chlorotoxin (CTX) and wasp venom mastoparan (MP-C) peptide $[30,73-76]$. 
G.

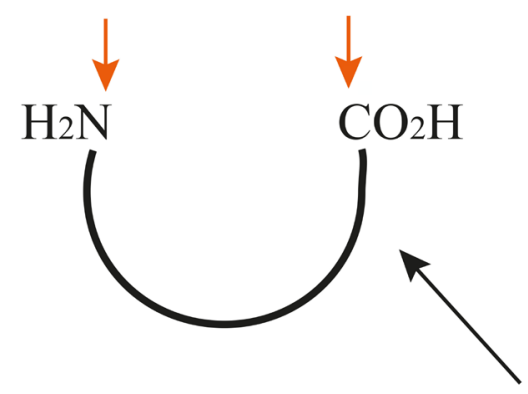

B.

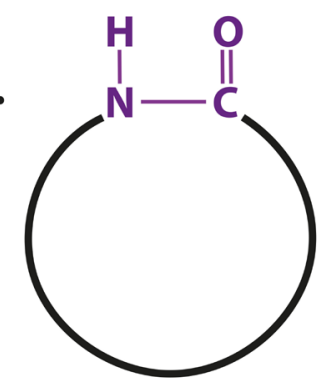

F.

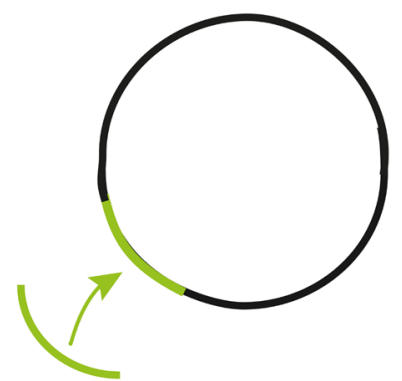

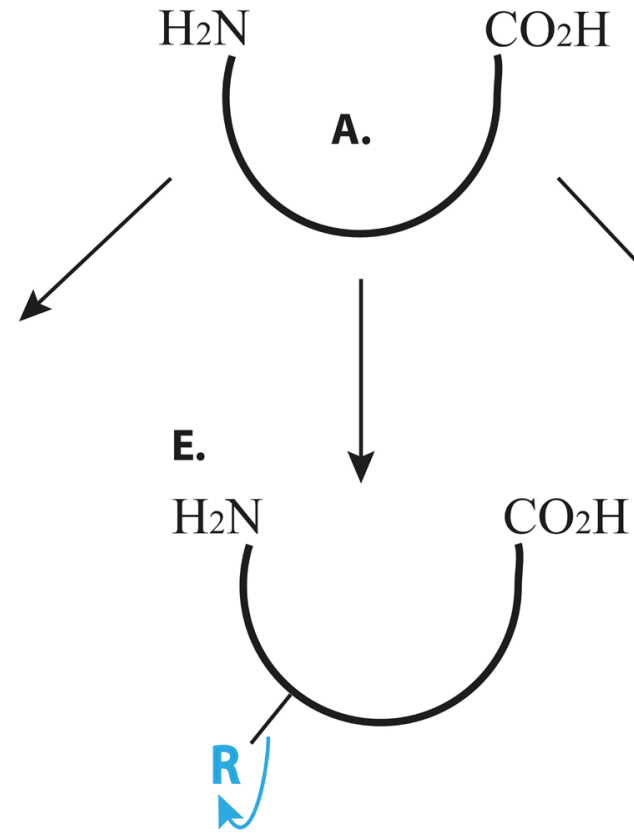

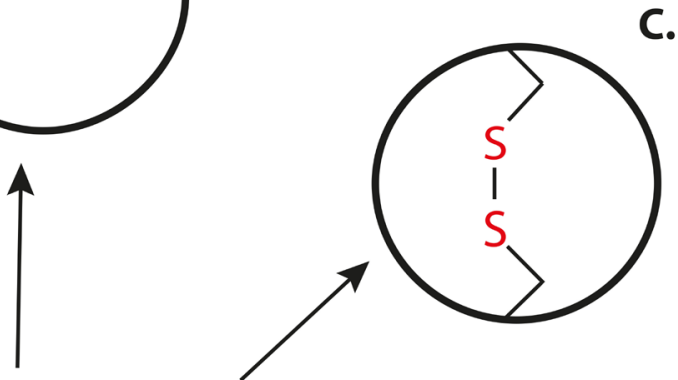

C.

D.

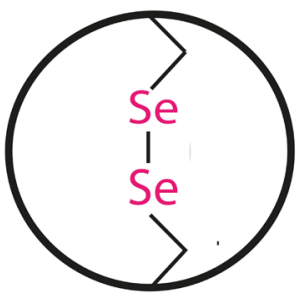

Figure 5. Strategies to increase peptide stability to make peptides resistant to proteases without affecting their bioactivities. A. linear peptide structure. B. head-to-tail peptide backbone cyclization. C. addition of disulfide bridges. D. addition of diselenide bridges. E. stereochemically inversion of amino acids (use of D-amino acids). F. grafting of an active peptide epitope and $\mathbf{G}$. capping the $\mathbf{N}$ - and C-terminals [Figure was adapted from reference 6].

\section{Grafting of Peptide Epitopes}

Placing bioactive short linear peptide epitopes on the peptide scaffolds with proven stability is known as grafting. It has been reported in many studies that the stability of the bioactive linear epitope can be increased by grafting [77-80]. Since the plant-derived peptides kalata B1, MCOTI-II and SFTI-1 peptides are highly resistant to chemicals, heat and enzymes, they have been used more in many peptide-based drug development studies than other peptides to date. Since these prototypic peptides can also be synthesized by solid phase peptide synthesis (SPPS) methods and can easily be folded correctly as their native forms, peptide epitope grafting studies in the literature have generally been applied by utilizing these three peptides.

In the literature, grafting studies are mainly carried out on the sixth loop of cyclotides, which appears to be tolerant to sequence replacements. Because the first and fourth loops of cyclotides form the main center and contain a limited number of amino acids (e.g. loop 1 has 3-4 residues and loop 4 has only one residue). The second loop is important for peptide folding as it can form salt bridges. The structure and properties of the 
peptide epitope are as important as the loop where the grafting will be performed. Abdul Ghani et al. studied the effect of structure and bioactivity by altering some mutual loops of kalata B1 and MCOTI-II and reported that the CCK motif is resistant to intact if covalent bond interactions do not occur, but bioactivity can vary greatly even with minor changes, including point mutations. Therefore, the previous literature data should be carefully examined before any grafting studies $[67,68]$.

Thrombospondin-1 (TSP-1) is a fragment of a sevenamino acid peptide with an anti-antigenogenic effect. In order to increase the stability of this peptide, grafting of the seven-residue bioactive epitope (GVITRIR) of TSP-1 onto MCOTI-II and SFTI-1 was reported in 2015. For both synthesized grafted peptides, the stability of the peptide epitope was increased while maintaining its bioactivity inherent as in native TSP-1 [81].

In another study, the bradykinin B1 receptor antagonists DALK peptide with nine amino acid residues was grafted onto loop 6 of kalata B1 for inflammatory pain treatment and reported notable stable in human serum for more than six hours with almost 90\% remained intact while DALK was degraded completely in this time period. In this study, it was also demonstrated that the grafted peptide was orally active [82]. In a following study, the peptide was also grafted separately on both loops of SFTI-1. The peptides were synthesized in both linear and cyclic forms [83]. The stability of each synthesized peptide was significantly increased, and the linear peptides exhibited less trypsin activity than bradykinin peptide epitope and cyclic grafted peptides.

\section{Peptide Analogs}

Peptide analogs harboring unnatural amino acids in the sequence are one of the strategies that can be used to enhance peptide stability against proteases. Polybia-CP, isolated from Polybia paulista wasp venom, is a 12 residue C-terminal amidated antimicrobial peptide. In 2017, Jia et al. synthesized its analog with D-amino acids in order to optimize the stability of this peptide and reported that the stability of the modified peptide was enhanced against trypsin and chymotrypsin enzymes. In the same study, the hemolytic effect of the peptide was significantly reduced compared to native Polybia- $\mathrm{CP}$, although the antimicrobial effect was slightly reduced [84].

The plant-derived kalata B1 peptide achieves many important bioactivities by its electrostatic interaction with the cell membrane. In 2011, Sando and colleagues synthesized kalata B1 with D-amino acids and investigated its effects on cell membrane compared to kalata B1 in its native form. D-kalata B1 was reported to have lower hemolytic activity. In addition, although the membrane affinity of D-kalata B1 was less, its anti-HIV activity, cytotoxicity, and hemolytic effect continued even they have slightly decreased [85].

In addition to cyclization, grafting and the use of unnatural amino acids, replacement of disulfide bonds by diselenide bonds, covalent coupling of the peptide with polyethyleneglycol (PEG) or lipids and truncation or capping of the $\mathrm{N}$ - and $\mathrm{C}$-terminals of the peptide have also been reported to increase the stability of the peptides [86-89].

In conclusion, disulfide-rich peptides found in plants and animals are promising drug scaffolds due to their high stabilities and diverse bioactivities including antimicrobial, anti-HIV, anticancer, analgesia, hypertension and more. Furthermore, although peptides have some drawbacks, they can be chemically modified to overcome the disadvantages such as stability and hemolytic activity and to contribute novel bioactivities.

\section{References}

1. P. Chames, M. Van Regenmortel, E. Weiss, D. Baty, Therapeutic antibodies: successes, limitations and hopes for the future, Br. J. Pharmacol., 157 (2009) 220-233.

2. N. Munoz-Durango, M.S. Pizarro-Ortega, E. Rey-Jurado, F.E. Diaz, S.M. Bueno, A.M. Kalergis, Patterns of antibody response during natural hRSV infection: insights for the development of new antibody-based therapies, Expert Opin. Investig. Drugs, 27 (2018) 721-731.

3. T.M. Pierpont, C.B. Limper, K.L. Richards, Past, present, and future of rituximab-the world's first oncology monoclonal antibody therapy, Front. Oncol., 8 (2018) 163.

4. J.L. Lau, M.K. Dunn, Therapeutic peptides: Historical perspectives, current development trends, and future directions, Bioorg. Med. Chem., (2017) 2700-2707.

5. R. Koradi, M. Billeter, K. Wuthrich, MOLMOL: A program for display and analysis of macromolecular structures, J. Mol. Graph., 14(1996) 51-55.

6. Ş. Kara, Tümör ile ilişkili peptidlerin sentezi ve kararlılıklarının incelenmesi-Synthesis and examination of stabilities of tumor-related peptides, M.Sc. Thesis, Number: 529178, Kütahya Dumlupınar University, Graduate School of Sciences, 2018.

7. L. Thorstholm, D.J. Craik, Discovery and applications of naturally occurring cyclic peptides, Drug Discov. Today Technol., 9 (2012) e1-e70. 
8. J. Koehbach, D.J. Craik, The Vast Structural Diversity of Antimicrobial Peptides, Trend. Pharmaco. Sci., 40 (2019) 517-528.

9. J.F. Borel, C. Feurer, H.U. Gubler, H. Stahelin, Biological effects of cyclosporin A: a new antilymphocytic agent, Agents Actions, 6 (1976) 468-475.

10. C. Spitzfaden, H.P. Weber, W. Braun, J. Kallen, G. Wider, H. Widmer, M.D. Walkinshaw, K. Wuthrich, Cyclosporin A-cyclophilin complex formation. A model based on X-ray and NMR data, FEBS Lett., 300 (1992) 291-300.

11. X. Yang, P. Feng, Y. Yin, K. Bushley, J.W. Spatafora, C. Wang, Cyclosporine biosynthesis in Tolypocladium inflatum benefits fungal adaptation to the environment, mBio, 9 (2018) e01211-01218.

12. J. Klages, C. Neubauer, M. Coles, H. Kessler, B. Luy, Structure refinement of cyclosporin a in chloroform by using RDCs measured in a stretched PDMS-gel, Chembiochem., 6 (2005) 1672-1678.

13. J.C. O'Shea, J.E. Tcheng, Eptifibatide: a potent inhibitor of the platelet receptor integrin glycoprotein IIb/IIla, Expert Opin. Pharmacother., 3 (2002) 1199-1210.

14. D.W. Cushman, M.A. Ondetti, History of the design of captopril and related inhibitors of angiotensin converting enzyme, Hypertension, 17 (1991) 589-592.

15. Lodha, M. Kamaluddeen, A. Akierman, H. Amin, Role of hemocoagulase in pulmonary hemorrhage in preterm infants: a systematic review, Indian J. Pediatrics., 78 (2011) 838-844.

16. S.J. Ho, T.A. Brighton, Ximelagatran: Direct thrombin inhibitor, Vasc. Health Risk Manag., 2 (2006) 49-58.

17. T.T. Vu, A.R. Stafford, B.A. Leslie, P.Y. Kim, J.C. Fredenburgh, J.I. Weitz, Batroxobin binds fibrin with higher affinity and promotes clot expansion to a greater extent than thrombin, J. Biol. Chem., 288 (2013) 16862-16871

18. T.M. A. El-Aziz, A.G. Soares, J.D. Stockand, Snake venoms in drug discovery: valuable therapeutic tools for life saving, Toxins, 11 (2019) E564.

19. Barnett, Exenatide, Expert Opin. Pharmacother., 8 (2007) 2593-2608.

20. W.R. Gray, A. Luque, B.M. Olivera, J. Barrett, L.J. Cruz, Peptide toxins from Conus geographus venom, J. Biolog. Chem., 256 (1981) 4734-4740.

21. H. Terlau, B.M. Olivera, Conus venoms: a rich source of novel ion channel-targeted peptides, Physiolog. Rev., 84 (2004) 41-68.

22. B. Gao, C. Peng, J. Yang, Y. Yi, J. Zhang, Q. Shi, Cone snails: a big store of conotoxins for novel drug discovery, Toxins, 9 (2017) E397.

23. H.M. Duque, S.C. Dias, O.L. Franco, Structural and functional analyses of cone snail toxins, Mar. Drugs, 17 (2019) E370.

24. K.K. Jain, An evaluation of intrathecal ziconotide for the treatment of chronic pain, Expert Opin. Investig. Drugs, 9 (2000) 2403-2410.

25. G.P. Miljanich, Ziconotide: Neuronal calcium channel blocker for treating severe chronic pain, Curr. Med. Chem., 11 (2004) 3029-3040.

26. R.J. Clark, H. Fischer, S.T. Nevin, D.J. Adams, D.J. Craik, The synthesis, structural characterization, and receptor specificity of the alpha-conotoxin Vc1.1, J. Biol. Chem., 281 (2006) 23254-23263.

27. J.A. DeBin, J.E. Maggio, G.R. Strichartz, Purification and characterization of chlorotoxin, a chloride channel ligand from the venom of the scorpion, Amer. J. Physiol. Cell Physiol., 264 (1993) C361-369.
28. A.N. Mamelak, S. Rosenfeld, R. Bucholz, A. Raubitschek, L.B. Nabors, J.B. Fiveash, S. Shen, M.B. Khazaeli, D. Colcher, A. Liu, M. Osman, B. Guthrie, S. Schade-Bijur, D.M. Hablitz, V.L. Alvarez, M A. Gonda, Phase I single-dose study of intracavitary-administered iodine-131-TM-601 in adults with recurrent high-grade glioma, J. Clin. Oncol., 24, (2006) 3644-3650.

29. M. Veiseh, P. Gabikian, S.B. Bahrami, O. Veiseh, M. Zhang, R.C. Hackman, A.C. Ravanpay, M.R. Stroud, Y. Kusuma, S.J. Hansen, D. Kwok, N.M. Munoz, R.W. Sze, W.M. Grady, N.M. Greenberg, R.G. Ellenbogen, J.M. Olson, Tumor paint: a chlorotoxin: Cy5.5 bioconjugate for intraoperative visualization of cancer foci, Cancer Res., 67 (2007) 68826888.

30. M. Akcan, M.R. Stroud, S.J. Hansen, R.J. Clark, N.L. Daly, D.J. Craik, J.M. Olson, Chemical re-engineering of chlorotoxin improves bioconjugation properties for tumor imaging and targeted therapy, J. Med. Chem., 54 (2011) 782-787.

31. C.G. Patil, D.G. Walker, D.M. Miller, P. Butte, B. Morrison, D.S. Kittle, S.J. Hansen, K.L. Nufer, K.A. Bymes-Blake, M. Yamada, L.L. Lin, K. Pham, J. Perry, J. Parrish-Novak, L. Ishak, T. Prow, K. Black, A.N. Mamelak, Phase 1 Safety, Pharmacokinetics, and fluorescence imaging study of tozuleristide (BLZ$100)$ in adults with newly diagnosed or recurrent gliomas, Neurosurgery, (2019) E641-E649.

32. A.C. Conibear, K.J. Rosengren, P.J. Harvey, D.J. Craik, Structural characterization of the cyclic cystine ladder motif of thetadefensins, Biochemistry, 51 (2012) 9718-9726.

33. Demori, Z.E. Rashed, V. Corradino, A. Catalano, L. Rovegno, L. Queirolo, S. Salvidio, E. Biggi, M. Zanotti-Russo, L. Canesi, A. Catenazzi, E. Grasselli, Peptides for skin protection and healing in amphibians, Molecules, 347 (2019) E347.

34. P. Escoubas, F. Bosmans, Spider peptide toxins as leads for drug development, Expert Opin. on Drug Discov., 2 (2007) 823-835.

35. R. Wehbe, J. Frangieh, M. Rima, D.E. Obeid, J.M. Sabatier, Z. Fajloun, Bee venom: overview of main compounds and bioactivities for therapeutic interests, Molecules, 24 (2019) E2997.

36. S.T. Henriques, D.J. Craik, Cyclotides as templates in drug design, Drug Discov. Today, 15 (2010) 57-64.

37. B. Franke, J.S. Mylne, K.L. Rosengren, Buried treasure: biosynthesis, structures and applications of cyclic peptides hidden in seed storage albumins, Nat. Prod. Rep., 35 (2018) 137-146.

38. Y.Q. Long, S.L. Lee, C.Y. Lin, I.J. Enyedy, S. Wang, P. Li, R.B. Dickson, P.P. Roller, Synthesis and evaluation of the sunflower derived trypsin inhibitor as a potent inhibitor of the type ॥ transmembrane serine protease, matriptase, Bioorg. Med. Chem. Lett., 11 (2001) 2515-2519.

39. M.L. Colgrave, M.J. Korsinczky, R.J. Clark, F. Foley, D.J. Craik, Sunflower trypsin inhibitor-1, proteolytic studies on a trypsin inhibitor peptide and its analogs, Biopolymers, 94 (2010) 665-672.

40. L. Gran, On the effect of a polypeptide isolated from "KalataKalata" (Oldenlandia affinis DC) on the oestrogen dominated uterus, Acta Pharmacol. Toxicol., 33 (1973) 400-408.

41. P.K. Pallaghy, K.J. Nielsen, D.J. Craik, R.S. Norton, A common structural motif incorporating a cystine knot and a triple stranded beta sheet in toxic and inhibitory polypeptides, Protein Sci., 3 (1994) 1833-1839.

42. O. Saether, D.J. Craik, I.D. Campbell, K. Sletten, J. Juul, D.G. Norman, Elucidation of the primary and three-dimensional structure of the uterotonic polypeptide kalata B1, Biochemistry, 34 (1995) 41474158. 
43. J. Weidmann, D.J. Craik, Discovery, structure, function, and applications of cyclotides: circular proteins from plants, J. Exp. Bot., 67 (2016) 4801-4812.

44. K.T.N. Giang, Y.L. Lian, E.W.H. Pang, Q.T.N. Phuong, T.D. Tran, J.P. Tam, Discovery of linear cyclotides in monocot plant Panicum laxum of poaceae family provides new insights into evolution and distribution of cyclotides in plants, J. Biolog. Chem., 288 (2013) 3370-3380.

45. S. Park, K. O. Yoo, T. Marcussen, A. Backlund, E. Jacobsson, K. J. Rosengren, I. Doo, U. Goransson, Cyclotide evolution: insights from the analyses of their precursor sequences, structures and distribution in violets (Viola), Front. Plant Sci., 8 (2017) 2058.

46. D.J. Craik, N.L. Daly, T. Bond, C. Waine, Plant cyclotides: a unique family of cyclic and knotted proteins that defines the cyclic cystine knot structural motif, J. Mol. Biol., 294 (1999) 1327-1336.

47. D.J. Craik, Joseph Rudinger memorial lecture: Discovery and applications of cyclotides (2013).

48. Y.H. Huang, Q. Du, D.J. Craik, Cyclotides: disulfide-rich peptide toxins in plants, Toxicon., 25 (2019) 33-44.

49. C.K. Wang, Q. Kaas, L. Chiche, D.J. Craik, CyBase: A database of cyclic protein sequences and structures, with applications in protein discovery and engineering, Nucleic Acids Res., 36 (2008) D206-210

50. M.L. Colgrave, D.J. Craik, Thermal, chemical, and enzymatic stability of the cyclotide kalata B1: The importance of the cyclic cystine knot, Biochemistry, 43 (2004) 5965-5975.

51. S. Gunasekera, N.L. Daly, R.J. Clark, D.J. Craik, Dissecting the oxidative folding of circular cystine knot miniproteins, Antioxid. Red. Signal., 11 (2009) 971-980.

52. T.L. Aboye, R.J. Clark, R. Burman, M.B. Roig, D.J. Craik, U Goransson, Interlocking disulfides in circular proteins: toward efficient oxidative folding of cyclotides, Antioxid Redox Signal., 14 (2011) 77-86.

53. C.V. Jennings, K.J. Rosengren, N.L. Daly, M. Plan, J. Stevens, M.J. Scanlon, C. Waine, D.G. Norman, M.A. Anderson, D.J. Craik, Isolation, solution structure, and insecticidal activity of kalata B2, a circular protein with a twist: do Mobius strips exist in nature? Biochemistry, 44 (2005) 851-860

54. C. Jennings, J. West, C. Waine, D. Craik, M. Anderson, Biosynthesis and insecticidal properties of plant cyclotides: the cyclic knotted proteins from Oldenlandia affinis, Proceedings of the National Academy of Sciences of the United States of America, 98 (2001) 10614-10619.

55. M.R. Plan, I. Saska, A.G. Cagauan, D.J. Craik, Backbone cyclised peptides from plants show molluscicidal activity against the rice pest Pomacea canaliculata (Golden Apple Snail) (2008) 5237-5241.

56. N.L. Daly, K.J. Rosengren, D.J. Craik, Discovery, structure and biological activities of cyclotides, Advan. Drug Deliver. Rev. 61 (2009) 918-930.

57. D.J. Craik, Host-defense activities of cyclotides, Toxins (Basel), 4 (2012) 139-156.

58. S.T. Henriques, Y.H. Huang, M. Castanho, L.A. Bagatolli, S. Sonza, G. Tachedjian, N.L. Daly, D.J. Craik, Phosphatidylethanolamine binding is a conserved feature of cyclotide-membrane interactions, J. Biologic. Chem., 287 (2012) 33629-33643.

59. S.T. Henriques, Y.H. Huang, S. Chaousis, M.A. Sani, A.G. Poth, F. Separovic, D.J. Craik, The prototypic cyclotide kalata B1 has a unique mechanism of entering cells, Chem. Biol., 22 (2015) 1087-1097.

60. L. Cascales, S. T. Henriques, M.C. Kerr, Y.H. Huang, M.J. Sweet, N.L. Daly, D.J. Craik, Identification and characterization of a new family of cell-penetrating peptides: cyclic cellpenetrating peptides, J. Biol. Chem., 286 (2011) 3693236943.
61. S.J. De Veer, J. Weidmann, D.J. Craik, D.J. Cyclotides as tools in chemical biology, Acc. Chem. Res., 50 (2017) 1557-1565.

62. Hermann, E. Syangard, P. Claeson, J. Gullbo, L. Bohlin, U. Göransson, Key role of glutamic acid for the cytotoxic activity of the cyclotide cycloviolacin $\mathrm{O}_{2}$, Cell. Mol. Life Sci., 63 (2006) 235-245.

63. P. Lindholm, U. Göransson, S. Johans, P. Claeson, J. Gullbo, R. Larsson, L. Bohlin, A. Backlund, Cyclotides: a novel type of cytotoxic agents, Molec. Cancer Therapeut., 1 (2002) 365369.

64. R. Burman, G.S. Stromstedt, M. Malmsten, U. Göransson, Cyclotide-membrane interactions: Defining factors of membrane binding, depletion and disruption, Biochimic. Biophysic. Acta, 1808 (2011) 2665-2673.

65. R. Burman, S. Gunasekera, A.A. Stromstedt, U. Goransson, Chemistry and biology of cyclotides: circular plant peptides outside the box, J. Nat. Prod., 77 (2014) 724-736.

66. R.J. Clark, M. Akcan, Q. Kaas, N.L. Daly, D.J. Craik, Cyclization of conotoxins to improve their biopharmaceutical properties, Toxicon., 59 (2012) 446-455.

67. D.J. Craik, J. Du, Cyclotides as drug design scaffolds, Curr. Opin. Chem. Biol., 38 (2017) 8-16.

68. C.K. Wang, D.J. Craik. Designing macrocyclic disulfide-rich peptides for biotechnological applications, Nat. Chem. Biol., 14 (2018) 417-427.

69. J.A. Camerero, M.J. Campbell, The potential of the cyclotide scaffold for drug development, Biomedicines, 7 (2019) E31.

70. P. G. Ojeda, M. H. Cardoso, O. H. Franco, Pharmaceutical applications of cyclotides, Drug Discover. Today, 24 (2019) 2152-2161.

71. R.J. Clark, J. Jensen, S.T. Nevin, B.P. Callaghan, D.J. Adams, Craik, The engineering of an orally active conotoxin for the treatment of neuropathic pain, Angew. Chem. Int. Ed., 49 (2010) 6545-6548

72. L.Y. Chan, V.M. Zhang, Y.H. Huang, N.C. Waters, P.S. Bansal, D.J. Craik, N.L. Daly, Cyclization of the antimicrobial peptide gomesin with native chemical ligation: influences on stability and bioactivity, Chembiochem., 14 (2013) 617-624.

73. M. Akcan, R.J. Clark, N.L. Daly, A.C. Conibear, A. de Faoite, M.D. Heghinian, T. Sahil, D.J. Adams, F. Mari, D.J. Craik, Transforming conotoxins into cyclotides: Backbone cyclization of P-superfamily conotoxins, Biopolymers, 104 (2015) 682-692.

74. R.J. Clark, H. Fischer, L. Dempster, N.L. Daly, K.J. Rosengren, S.T. Nevin, F.A. Meunier, D.J. Adams, D.J. Craik, Engineering stable peptide toxins by means of backbone cyclization: stabilization of the alpha-conotoxin MII, Proc. Nat. Acad. Sc., 102 (2005) 1376713772.

75. X. Chen, L. Zhang, Y. Wu, L. Wang, C. Ma, X. Xi, O.R. P. BinindaEmonds, C. Shaw, T. Chen, M Zhou, Evaluation of the bioactivity of a mastoparan peptide from wasp venom and of its analogues designed through targeted engineering, Int. J. Biol. Sci., 14 (2018) 599-607.

76. N. Lawrence, A.S.M. Dennis, A.M. Lehane, A. Ehmann, P.J. Harvey, A.H. Benfield, O. Cheneval, S.T. Henriques, D.J. Craik, B.J. McMorran, Defense peptides engineered from human platelet factor 4 kill plasmodium by selective membrane disruption, Cell. Chem. Biol., 25 (2018) 1140-1150.

77. P. Quimbar, U. Malik, C.P. Sommerhoff, Q. Kaas, L.Y. Chan, Y.H. Huang, M. Grundhuber, K. Dunse, D.J. Craik, M.A. Anderson, N.L. Daly, High-affinity cyclic peptide matriptase inhibitors, J. Biol. Chem., 288 (2013) 13885-13896.

78. C.K. Wang, C.W. Gruber, M. Cemazar, C. Siatskas, P. Tagore, N. Payne, G. Sun, S. Wang, C.C. Bernard, D.J. Craik, Molecular grafting onto a stable framework yields novel cyclic peptides for the treatment of multiple sclerosis, ACS Chem. Biol., 9 (2014) 156-163. 
79. C. D'Souza, S.T. Henriques, C.K. Wang, O. Cheneval, L.Y. Chan, N.J. Bokil, M.J. Sweet, D.J. Craik, Using the MCoTI-II cyclotide scaffold to design a stable cyclic peptide antagonist of set, a protein overexpressed in human cancer, Biochemistry, 55 (2016) 396-405

80. C. Cobos Caceres, P.S. Bansal, S. Navarro, D. Wilson, L. Don, P. Giacomin, A. Loukas, N. L. Daly, An engineered cyclic peptide alleviates symptoms of inflammation in a murine model of inflammatory bowel disease, J. Biol. Chem., 292 (2017) 10288-10294.

81. L.Y. Chan, D.J. Craik, N.L. Daly, Cyclic thrombospondin-1 mimetics: grafting of a thrombospondin sequence into circular disulfide-rich frameworks to inhibit endothelial cell migration, Biosci. Rep., 35 (2015) e00270.

82. C.T.T. Wong, D.K. Rowlands, C.H. Wong, T.W.C. Lo, G.K.T. Nguyen, H.Y. Li, J.P. Tam, Orally active peptidic bradykinin B1 receptor antagonists engineered from a cyclotide scaffold for inflammatory pain treatment, Angew. Chem. Int. Ed., 51 (2012) 5620-5624.

83. Y. Qiu, M. Taichi, N. Wei, H. Yang, K.Q. Luo, J.P. Tam, An Orally active bradykinin B1 receptor antagonist engineered as a bifunctional chimera of sunflower trypsin inhibitor, J. Med. Chem., 60 (2017) 504-510.
84. F. Jia, J. Wang, J. Peng, P. Zhao, Z. Kong, K. Wang, W. Yan, R. Wang, D-amino acid substitution enhances the stability of antimicrobial peptide polybia-CP, Acta Biochim. Biophys. Sin. (Shanghai), 49 (2017) 916-925.

85. L. Sando, S.T. Henriques, F. Foley, S.M. Simonsen, N.L. Daly, K.N. Hall, K.R. Gustafson, M.I. Aguilar, D.J. Craik, A Synthetic mirror image of kalata B1 reveals that cyclotide activity is independent of a protein receptor, Chembiochem., 12 (2011) 2456-2462.

86. C.J. Armishaw, N.L. Daly, S.T. Nevin, D.J. Adams, D.J., Craik, P.F. Alewood, alpha-selenoconotoxins, a new class of potent alpha(7) neuronal nicotinic receptor antagonists, J. Biologi. Chem., 281 (2006) 14136-14143.

87. J. Kindrachuk, E. Scruten, S. Attah-Poku, K. Bell, A. Potter, L.A. Babiuk, P J. Griebel, S. Napper, Stability, toxicity, and biological activity of host defense peptide BMAP28 and its inversed and retro-inversed isomers, PeptideScience, 96 (2010) 14-24

88. D.J. Craik, D.J. Adams, Chemical modification of conotoxins to improve stability and activity, Acs Chem. Biol., 2 (2007) 457-468.

89. N. Yin, Enhancing the oral bioavailability of peptide drugs by using chemical modification and other approaches, Medicin. Chem., 4 (2014) 763-769. 